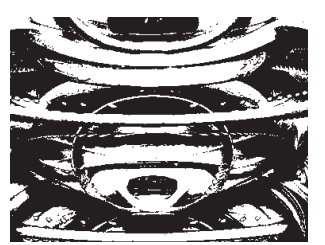

\title{
MOTIVATION FOR SUBSTANCE USE: WHY DO PEOPLE USE ALCOHOL, TOBACCO AND MARIJUANA?
}

Renata GLAVAK TKALIĆ, Ines SUČIĆ, Ivan DEVIĆ Institute of Social Sciences Ivo Pilar, Zagreb

UDK: 316.6:178

Izvorni znanstveni rad

Primljeno: 8. 3. 2013.

The research aimed to explore the salience of different motives for substance use among alcohol, tobacco and marijuana users, and to investigate the difference in motives' salience with regard to frequency of substance use and respondents' socio-demographic characteristics. Data were collected among subsamples of alcohol, tobacco and marijuana users drawn from the representative sample of Croatian citizens ( $N=4756)$. Respondents assessed four types, and for marijuana use five types of motives for each substance use (enhancement, social, conformity, coping, and expansion). The enhancement motives were assessed as the most, and conformity motives as the least salient motives among all groups of substance users. Generally, enhanced salience of motives was related to the frequency of all types of substance use. While age had significant effect on the salience of social motives for tobacco use, gender and marital status had significant effect on the salience of all motives for alcohol use, and age had significant effect only on the salience of enhancement and social motives for alcohol use. Among marijuana users, only marital status had significant effect on the salience of expansion motives for marijuana use. Results are discussed within the framework of motivational models for substance use.

Keywords: alcohol, tobacco, marijuana, motives for substance use, socio-demographic variables

Renata Glavak Tkalić, Institute of Social Sciences Ivo Pilar, Marulićev trg 19/1, P. O. Box 277, 10001 Zagreb, Croatia. E-mail: Renata.Glavak.Tkalic@pilar.hr 


\section{INTRODUCTION}

\section{Motives for substance use and its measurement}

Motivation for substance use along with the knowledge of its patterns and prevalence help us understand the risk factors, context, circumstances and probable consequences of such behavior, but also how to develop effective prevention and intervention programs (Cooper, 1994; Newcomb, Chou, Bentler, \& Huba, 1988). Motivational models suggest that substance use motives represent the common pathway for its actual use (e.g. Lyvers, Hasking, Hani, Rhodes, \& Trew, 2010) and thus present research tries to explore motives for using the most common (il)licit substances: alcohol, tobacco, and marijuana.

Cox and Klinger (1988) proposed two underlying dimensions of drinking motives: the source and the valence of the outcomes an individual wants to achieve by drinking. Their crossing results with four specific motives for drinking (Cooper, 1994): enhancement (internal, positive reinforcement), social (external, positive reinforcement), coping (internal, negative reinforcement), and conformity motives (external, negative reinforcement). This four-dimensional structure of drinking motives was confirmed on both adolescents and young adults (Kuntsche, Knibbe, Gmel, \& Engels, 2006a; MacLean \& Lecci, 2000), and adults (Crutzen \& Kuntsche, 2013; Engels, Wiers, Lemmers, \& Overbeek, 2005).

Rossi, Prochaska, and DiClemente (1988) identified six factors for smoking while Tate, Pomerleau, and Pomerleau (1994) identified seven. Among them, sedative, psychosocial, and stimulation motives are equivalent to coping, conformity, and enhancement motives found for drinking, respectively, suggesting that the same motivational model may also apply to tobacco use (Comeau, Stewart, \& Loba, 2006).

While there is a long history of research into motives underlying alcohol and tobacco use, and several different self-report measures of substance use motivation are commonly used in the research (e.g. Reasons for Smoking Scale (RSS) by Ikard, Green, \& Horn, 1969; Drinking Motive Questionnaire Revised (DMQ-R) by Cooper, 1994), the literature on motivation for marijuana use is relatively limited and has primarily been adapted from previous research on alcohol use motives (e.g. Marijuana Motives Measure (MMM), Simons, Correia, Carey, \& Borsari, 1998; for more details see Lee, Neighbors, Hendershot, \& Grossbard, 2009). Simons et al., (1998) in order to explain marijuana use motives, expanded the four-dimensional motivational model for drinking with an additional factor, named expansion (for MMM dimension see also Chabrol, Ducongé, Casas, Roura, \& Carey, 2005; Zvolensky et al., 2007), while more 
DRUŠ. ISTRAŽ. ZAGREB GOD. 22 (2013), BR. 4 STR. $601-625$

GLAVAK TKALIĆ, R., SUČIĆ, I., DEVIĆ, I. MOTIVATION FOR.

recent research identified a higher number (e.g. 12) of specific marijuana use motives (e.g. by using Comprehensive Marijuana Motives Questionnaire by Lee et al., 2009).

Although the comparison of these different motivational measures with regard to their psychometric properties revealed that those scales are multidimensional measures, and that they pose distinct, replicable, and internally consistent factors of specific substance use motives (e.g. Simons, Correia, \& Carey, 2000), some researchers pointed to the lack of agreement on how to best conceptualize substance use motives. High inter-correlations among certain factors are common, and in the context of overall addictive behavior, some researchers propose that there may be two higher-order factors for substance use motives, namely negative and positive reinforcement motive dimensions (Pomerleau, Fagerström, Marks, Tate, \& Pomerleau, 2003; Battistaet al., 2008).

\section{Relationship between motives and substance use}

In general, greater salience of all identified motives is adversely related to substance use. Coping motives (reduction or avoidance of negative emotions, boredom, sedative motives) were found to be related to heavier drinking problems (Bradizza, Reifman, \& Barnes, 1999; Carey \& Correia, 1997; Lyvers et al., 2010), increased levels of alcohol use (Cooper, 1994; Kuntsche, Knibbe, Gmel, \& Engels, 2006b), more chronic smoking behavior (Tate et al., 1994), and increased levels of marijuana use (Simons et al., 1998; Lee et al., 2009). Similarly, more salient conformity motives for substance use (reduction or avoidance of social censure, psychosocial motives) were also related to heavier drinking problems (Bradizza et al., 1999; Carey \& Correia, 1997; Lyvers et al., 2010), faster smoking rate (Tate et al., 1994), and more pronounced problems related to marijuana use (Simons et al., 1998). Enhancement (increase of positive mood states, enjoyment, stimulation) was related to increased levels of alcohol use (Cooper, 1994; Kuntsche et al., 2006b), more chronic smoking behavior and faster smoking rate (Tate et al., 1994), increased levels of marijuana use (Simons et al., 1998; Lee et al., 2009), and more problems associated with marijuana use (Lee, Neighbors, \& Woods, 2007), and along with stress relief (coping), was the most commonly reported motive for smoking (Fidler \& West, 2009). Altered perception or perspectives (expansion motives) was associated with heavier marijuana use and more problems associated with its use (Lee et al., 2007), and also greater frequency of marijuana use (Lee et al., 2009). Social motives (obtaining positive social rewards) were more related to light, infrequent, non-problematic alcohol use and with drinking in social settings (Cooper, 
encing negative consequences of marijuana use (Simons et al., 1998).

\section{Socio-demographic correlates of motives for substance use}

There are many factors (e.g. socio-demographics, presence of other physical and/or psychological problems) influencing both type and frequency of substance use, and also salience of certain motives for substance use. Due to potential relevance of such factors and at the same time inconclusiveness of the obtained findings concerning their influence, it is worth considering if the socio-demographic characteristics, such as age, gender and marital status, are relevant for substance use motives.

Gender differences in motives for alcohol use have been well described, but they do not always occur (Kuntsche et al., 2006b). It seems they emerge later in life since the increase in social and enhancement motives, and decrease in coping motives for drinking among males was not noticed before late adolescence (Cooper, 1994), and adulthood (Carrigan, Samoluk, \& Stewart, 1998; Smith, Abbey, \& Scott, 1993; Kairouz, Gliksman, Demers, \& Adlaf, 2002). On the other hand, some research found that girls score higher on coping motives for alcohol use in early adolescence (Cooper, 1994), while conformity motives were often found to be more strongly related to alcohol use in men (Cooper, 1994). It seems that women are more motivated for tobacco use by the motives of reduction of negative affect and pleasure than men (Livson \& Leino, 1998), and that the relationship between coping motives and marijuana use was higher in women (Simons et al., 1998). On the other hand, salience of enhancement, social, and expansion motives for marijuana use was higher in men than women (Hawkins, 2006).

With regard to age, Kuntsche, Knibbe, Gmel, and Engels (2005) found that most adolescents reported social motives for drinking, some indicated enhancement motives, and only a few reported coping motives. Also, young adults were more likely to drink for social and enhancement motives than older ones (Kim \& Jeon, 2012). Furthermore, younger smokers rated socializing motives as more important than older smokers, who rated the enjoyment motives for tobacco use as more important (Livson \& Leino, 1998).

Marriage can be perceived as an indicator of maturity, but also indicator of willingness to commit and readiness to accept responsibilities. It might significantly influence health-promoting behavior and the salience of specific motives that influence such behaviors. For example, Kim and Jeon (2012) found that participants without spouses reported greater importance of social motives and enhancement motives for alcohol use than those with spouses. Since there is a major gap in the literature in this area, this issue is yet to be further explored. 
It is unclear whether specific substance use motives uniquely contribute to the prediction of particular substance use or that common motivational factors underlie several, if not all substance use motives (Lee et al., 2009). The extent to which motives vary across substance types, and across severity of substance use has yet to be determined (Simons et al., 2000). Existing motivational models shed light on the potential causes of substance use, but were primarily focused on motives for single substance use (e.g. alcohol) and among one age-specific group (young people).

Thus, this study aimed to explore differences in the salience of different motives for several, the most commonly used (il)licit substances - alcohol, tobacco, and marijuana. Also, this study explores motives for substance use with regard to the frequency of its use, and with regard to age, gender and marital status wishing to fill the gap in research on the role socio-demographic variables play in the motivation for substance use, and to explore specificities and commonalities in the motive salience for substance use between different respondents' categories.

\section{METHODS}

\section{Sample}

(1) TABLE 1

Gender, age and marital status of respondents by subsamples

The research was carried out on a representative sample of Croatian citizens $(\mathrm{N}=4756)$, aged between 15 and 64 years, living in private households. ${ }^{1}$ The research was based on a single cross-sectional design, and the response rate was $53.1 \% .^{2}$

\begin{tabular}{|c|c|c|c|c|c|c|c|}
\hline \multirow[b]{2}{*}{ Users } & & \multicolumn{2}{|c|}{ Alcohol } & \multicolumn{2}{|c|}{ Tobacco } & \multicolumn{2}{|c|}{ Marijuana } \\
\hline & & $\mathrm{N}$ & $\%$ & $\mathrm{~N}$ & $\%$ & $\mathrm{~N}$ & $\%$ \\
\hline \multirow[t]{3}{*}{ Gender } & Male & 1539 & 55.4 & 827 & 48.5 & 431 & 61.0 \\
\hline & Female & 1241 & 44.6 & 877 & 51.5 & 276 & 39.0 \\
\hline & Total & 2780 & 100.0 & 1704 & 100.0 & 707 & 100.0 \\
\hline \multirow[t]{6}{*}{ Age } & $15-24$ & 611 & 22.1 & 349 & 20.5 & 218 & 31.0 \\
\hline & $25-34$ & 712 & 25.7 & 436 & 25.6 & 284 & 40.4 \\
\hline & $35-44$ & 454 & 16.4 & 348 & 20.5 & 125 & 17.8 \\
\hline & $45-54$ & 498 & 18.0 & 309 & 18.2 & 60 & 8.5 \\
\hline & $55-64$ & 494 & 17.8 & 258 & 15.2 & 16 & 2.3 \\
\hline & Total & 2769 & 100.0 & 1700 & 100.0 & 703 & 100.0 \\
\hline \multirow[t]{3}{*}{ Marital status } & Married & 1448 & 52.3 & 882 & 51.9 & 207 & 29.6 \\
\hline & Unmarried & 1320 & 47.7 & 819 & 48.1 & 493 & 70.4 \\
\hline & Total & 2768 & 100.0 & 1701 & 100.0 & 700 & 100.0 \\
\hline
\end{tabular}

For the purpose of this study data analyses were performed on three subsamples of respondents: those who re- 
DRUŠ. ISTRAŽ. ZAGREB GOD. 22 (2013), BR. 4, STR. $601-625$

GLAVAK TKALIĆ, R., SUČIĆ, I., DEVIĆ, I.: MOTIVATION FOR...

\section{Instruments}

ported drinking alcohol in the month prior to the research (alcohol users), those who reported smoking tobacco in the month prior to the research (tobacco users), and those who reported ever using marijuana in their lives (marijuana users). Characteristics of each subsample are presented in Table 1.

This survey was a part of the larger project entitled Substance abuse among the general population of the Republic of Croatia. Directions and methodological guidelines for this survey were developed by the European Monitoring Centre for Drugs and Drug Addiction (EMCDDA) experts, and the Croatian translation of the European Model Questionnaire (EMQ) (EMCDDA, 2002) was used. This is a standard instrument in surveys for measuring prevalence and frequency of substance use, providing cross-nationally reliable and comparable measures of the extent and patterns of substance use amongst the general population. Croatian translations and back-translations (to English) of all questionnaires used in this research were done in accordance to guidelines proposed in the methodological literature pertaining to cross-cultural psychology.

Prevalence of substance use. For alcohol and tobacco use, a measure of last month prevalence was used. Since marijuana use is much less frequent among the general population, the measure of lifetime prevalence was used. ${ }^{3}$

Last month frequency of substance use. For alcohol and marijuana use, respondents indicated the number of days they used a particular substance in the month prior to the research (possible answers: 20 days or more, 10-19 days, 4-9 days, 1-3 days), and for the tobacco use they indicated the number of cigarettes they smoked daily (possible answers: I do not smoke every day, $\leq 5$ cigarettes, 5-10, 10-20, 20-30, 30-40, > 40 cigarettes per day).

Socio-demographic variables included gender (male/female), age, and marital status of respondents (married/unmarried). Due to specific interest in difference in salience of substance use motives among different socio-demographic groups of respondents, and enhanced clarity of data reporting when all variables are in similar mode (gender and marital status were initially categorical), respondents were categorized into five age groups (15-24, 25-34, 35-44, 45-55, 55-64 years). ${ }^{4}$

In accordance with previously discussed patterns of convergence between different substance use motives (e.g. Simons et al., 2000), previous practices of assessing motives for tobacco use (e.g. Pomerleau, Pomerleau, Flessland, \& Basson, 1992), and marijuana use (e.g. Simons et al., 1998; Simons et al., 2000) by modification of Cooper's (1994) Drinking Motives Question- 
DRUŠ. ISTRAŽ. ZAGREB GOD. 22 (2013), BR. 4 STR. $601-625$

GLAVAK TKALIĆ, R., SUČIĆ, I., DEVIĆ, I. MOTIVATION FOR.

$\rightarrow$ TABLE 2

Internal consistency coefficients by subscales for substance use

\section{Procedure}

naire Revised (DMQ-R), and in order to assure comparison among motives but also to reduce subject burden and save time and costs, a shortened version of the DMQ-R for measuring substance use motives was used. DMQ-R and its modifications for measuring tobacco and marijuana use were already verified in the Croatian sample, and a shortened version of the DMQ-R was created from the items showing the best psychometric characteristics (Dejanović, 2011). Participants rated on a 5-point Likert scale (from almost never/never to almost always/always) how frequently each of the listed reasons motivate them to use a specific substance. Enhancement reflects substance use for enhancing positive mood or well-being (e.g. "I drink because it is fun"), Coping reflects substance use to reduce or regulate negative emotions (e.g. "I drink to forget about my problems"), Conformity reflects substance use to avoid social censure or rejection (e.g. "I drink so I won't feel left out"), and Social reflects substance use to enhance positive social rewards (e.g. "I drink because it makes social gatherings more fun"). Expansion reflects marijuana use to expand new experiences (e.g. "I use marijuana so I can expand my awareness"), and was added for measuring the motive specific for marijuana use. Subscale scores were calculated as the sum of the responses to the respective items divided by the number of items included, with higher scores indicating more salient motives. Internal consistency coefficients ranged from middle to high (Table 2). Lower consistency of some subscales is not surprising since each subscale was represented by only two items.

\begin{tabular}{lccc}
\hline Motives & Alcohol use & Tobacco use & Marijuana use \\
\hline Enhancement & 0.65 & 0.79 & 0.81 \\
Coping & 0.74 & 0.70 & 0.79 \\
Conformity & 0.80 & 0.79 & 0.77 \\
Social & 0.74 & 0.78 & 0.71 \\
Expansion & - & - & 0.77 \\
\hline
\end{tabular}

The data was gathered by face-to-face interviews in the respondents' households by trained interviewers. For the purpose of this survey only one person per household was selected to participate in the survey. The interviewing took approximately 20 minutes. Participation in the research was voluntary and anonymous, and all collected information was confidential. The Croatian Psychological Chamber's recommendations were followed for minors (aged 15-17 years), and parental consent for the interviewed children was assured. 


\section{RESULTS}

Substance use motives' salience with regard to the type of substance use

Conformity motives for substance use were ranked as the least present and enhancement motives as the most present of all motives among all groups of users (Table 3). Differences between (il)licit substance use motives' salience within different groups of substance users were tested using one-way repeated measures ANOVA, and statistically significant differences

(1) TABLE 3

Descriptive statistics

and differences

between substance use

motives' salience

among alcohol,

tobacco, and

marijuana users were found between pronouncement of motives for (il)licit substance use in each of the substance users' groups. Comparison of the main effects showed significant differences between salience of all four motives for alcohol and tobacco use, and all five motives for marijuana use except coping and social motives, and conformity and expansion motives (Table 3). ${ }^{5}$

\begin{tabular}{lrrrrrrrrrr}
\hline Users/Motives & $\mathrm{N}$ & $\mathrm{M}$ & $\mathrm{SD}$ & $\mathrm{MS}$ & $\mathrm{F}$ & $\mathrm{df}$ & $\mathrm{p}$ & $\begin{array}{r}\text { Partial } \\
\eta^{2}\end{array}$ & $\begin{array}{r}\text { Observed } \\
\text { power }\end{array}$ \\
\hline $\begin{array}{l}\text { Alcohol } \\
\quad \text { enhancement }\end{array}$ & 2749 & 2.52 & 1.158 & 794.545 & 1350.511 & 2.829 & 0.000 & 0.331 & 1.000 \\
$\quad$ coping & 2759 & 1.80 & 0.999 & & & & & & \\
$\quad \begin{array}{l}\text { conformity } \\
\text { social }\end{array}$ & 2759 & 1.33 & 0.711 & & & & & & \\
Tobacco & 2758 & 2.26 & 1.189 & & & & & & \\
$\quad$ enhancement & 1678 & 3.56 & 1.208 & 1471.109 & 1544.242 & 2.586 & 0.000 & 0.481 & 1.000 \\
$\quad$ coping & 1682 & 2.31 & 1.157 & & & & & & \\
$\quad$ conformity & 1682 & 1.51 & 0.904 & & & & & & \\
$\quad$ social & 1684 & 2.04 & 1.196 & & & & & & \\
Marijuana & & & & & & & & & \\
$\quad$ enhancement & 684 & 2.76 & 1.369 & 227.221 & 252.738 & 3.299 & 0.000 & 0.274 & \\
$\quad$ coping & 680 & 1.75 & 1.092 & & & & & & \\
$\quad$ conformity & 685 & 1.43 & 0.833 & & & & & & \\
$\quad$ social & 683 & 1.80 & 1.012 & & & & & & \\
$\quad$ expansion & 683 & 1.55 & 0.978 & & & & & & \\
\hline
\end{tabular}

\section{Substance use motives' salience with regard \\ to the frequency of specific substance use}

MANOVA showed significant differences in the salience of different motives for substance use with regard to the frequency of substance use for: alcohol use $(F(12,8046)=16.54, p=0.000)$, tobacco use $(F(16,6208)=5.33, p=0.000)$, and marijuana use $(F(15,360)=2.79, p=0.001)$.

Among alcohol users, there were significant differences in the salience of all motives with regard to the frequency of alcohol use in the last month (for enhancement motives 
DRUŠ. ISTRAŽ. ZAGREB GOD. 22 (2013), BR. 4 STR. 601-625

GLAVAK TKALIĆ, R., SUČIĆ, I., DEVIĆ, I.. MOTIVATION FOR..

$\rightarrow$ FIGURE 1

Salience of motives for drinking alcoholic beverages among alcohol users with regard to frequency of use

FIGURE 2

Salience of motives for smoking tobacco

among tobacco users with regard to frequency of use
$F(3,2683)=42.02, p=0.000$, for coping motives $F(3,2683)=34.97$, $p=0.000$, for conformity motives $F(3,2683)=0.57, p=0.003$, and for social motives $F(3,2683)=13.20, p=0.000)$. Those who drank alcoholic beverages from 4 to 9 days in the past month had significantly less pronounced enhancement and social motives than those who drank alcoholic beverages 20 or more days in the month prior to the research. Those who drank alcoholic beverages from 1 to 3 days in the past month had significantly less pronounced all four motives for drinking than those who drank alcoholic beverages 4 to 9 days in the month prior to the research. They also had significantly less pronounced enhancement, coping and conformity motives for drinking than those who drank alcoholic beverages 10 to 19 days in the month prior to the research, and less pronounced enhancement and coping motives than those who drank alcoholic beverages 20 or more days in the month prior to the research (see Figure 1).

FIGURE 3

Salience of motives for smoking marijuana among marijuana users with regard to frequency of use

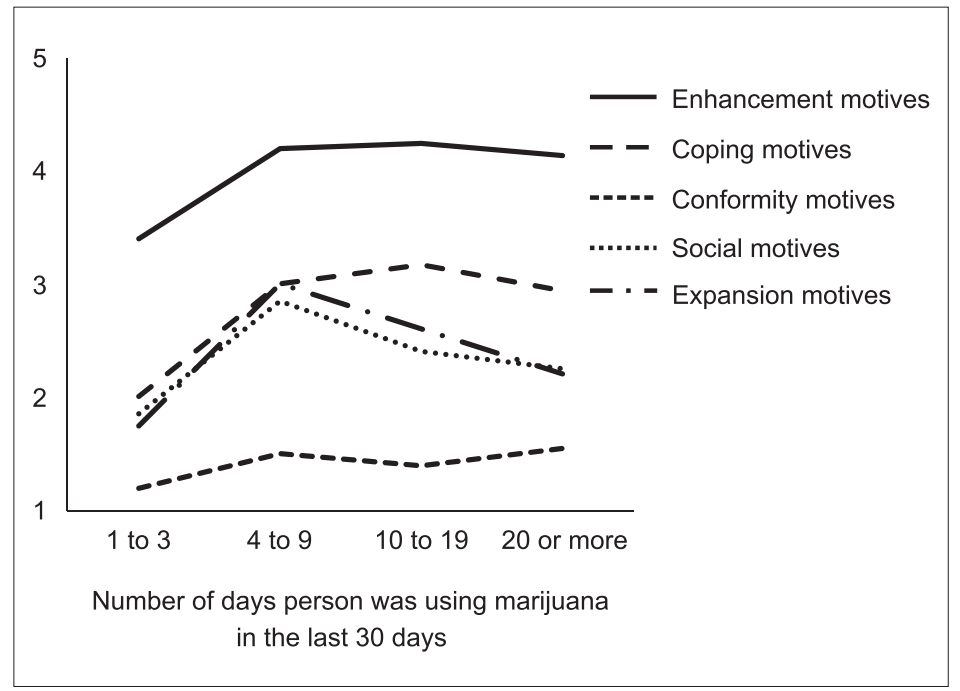

There were significant differences among tobacco users in the salience of enhancement motives $(F(4,1552)=13.93$, $p=0.000)$, and coping motives $(F(4,1552)=6.32, p=0.000)$ with regard to the frequency of smoking in the month prior to the research. Post hoc test showed that respondents who smoked 20-30 cigarettes and those who smoked more than 30 cigarettes per day had more significantly pronounced enhancement motives than those who smoked 5-10 cigarettes per day, and those who smoked less than 5 cigarettes per day. Also, those who smoked 20-30 cigarettes per day had more significantly pronounced enhancement motives than those who smoked 10-20 cigarettes per day. Also, those who smoked 10-20 cigarettes per day had more pronounced enhancement motives than those who smoked less than 5 cigarettes per day. Those who smoked less than 5 cigarettes per day had significantly less pronounced coping motives than those who smoked 20-30 and 30 and more cigarettes per day (see Figure 2).

Among marijuana users, there were also significant differences in the salience of enhancement $(F(3,122)=7.52, p=0.000)$, coping $(F(3,122)=5.30, p=0.002)$, social $(F(3,122)=4.11, p=$ $0.008)$, and expansion $(F(3,122)=6.75, p=0.000)$ motives with regard to the frequency of marijuana use in the last month. Those who used marijuana from 1 to 3 days in the last month had less salient enhancement, social and expansion motives than those who used it from 4 to 9 days in the last month. Also, they had less salient enhancement and coping motives than those who used marijuana from 10 to 19 days, and less salient enhancement motives than those who used it 20 or more days in the month prior to the research (see Figure 3). ${ }^{6}$ 


\section{Substance use motives' salience with regard to gender, age, and marital status}

Among alcohol users, there were significant main effects of gen$\operatorname{der}(F(4,2649)=6.67, p=0.000)$, age $(F(16,10608)=5.03, p=$ $0.000)$, and marital status $(F(4,2649)=7.19, p=0.000)$ on the salience of different motives for alcohol use. Among those who drank alcoholic beverage(s) in the last month, there were differences between salience of all motives for alcohol use with regard to gender $(F(1,2652)=24.68, p=0.000$ for enhancement motives, $F(1,2652)=11.85, p=0.001$ for coping motives, $F(1,2652)=4.34, p=0.037$ for conformity motives, $F(1,2652)=$ $4.27, p=0.039$ for social motives), and with regard to marital status $(F(1,2652)=18.15, p=0.000$ for enhancement motives, $F(1,2652)=23.89, p=0.000$ for coping motives, $F(1,2652)=7.44$, $p=0.006$ for conformity motives, $F(1,2652)=15.18, p=0.000$ for social motives). Generally, men in comparison to women, and unmarried persons in comparison to those married, reported being significantly more motivated by enhancement, coping, conformity and social motives for alcohol use (Figure 4a and 4c). Significant differences in salience of enhancement $(F(4,2652)=$ $4.12, p=0.000)$ and social $(F(4,2652)=17.08, p=0.000)$ motives for alcohol use were found with regard to the age of respondents. Post hoc tests showed that the youngest respondents (aged 15-24) were more motivated for alcohol use by enhancement motives than respondents from all other age groups (25-34, 35-44, 45-54, 55-64), and the respondents aged 25-34 were more motivated for alcohol use by enhancement motives than the ones from the older age groups (45-54, and 55-64). Also, respondents from the two youngest age groups (15-24 and 25-34) were statistically significantly more motivated for alcohol use by social motives compared to respondents from all other older age groups (Figure $4 b$ ).

Differences between salience of different motives for substance use among alcohol tobacco, and marijuana users with regard to gender, age and marital status overall MANOVA results $^{7}$

\begin{tabular}{llrrrrr}
\hline & & & & & $\begin{array}{r}\text { Partial } \\
\eta^{2}\end{array}$ & $\begin{array}{r}\text { Observed } \\
\text { power }\end{array}$ \\
\hline Gender & Users & F & df & p & & \\
& Alcohol & 6.673 & 4 & 0.000 & 0.010 & 0.993 \\
& Tobacco & 0.416 & 4 & 0.797 & 0.001 & 0.148 \\
Age & Marijuana & 1.103 & 5 & 0.357 & 0.009 & 0.396 \\
& Alcohol & 5.034 & 16 & 0.000 & 0.008 & 1.000 \\
& Tobacco & 2.419 & 16 & 0.001 & 0.006 & 0.992 \\
Marital status & Marijuana & 1.016 & 20 & 0.439 & 0.008 & 0.780 \\
& Alcohol & 7.192 & 4 & 0.000 & 0.011 & 0.996 \\
& Tobacco & 2.156 & 4 & 0.072 & 0.005 & 0.641 \\
& Marijuana & 2.534 & 5 & 0.028 & 0.020 & 0.790 \\
\hline
\end{tabular}


DRUŠ. ISTRAŽ. ZAGREB GOD. 22 (2013), BR. 4 STR. 601-625

GLAVAK TKALIĆ, R.,

SUČIĆ, I., DEVIC, I.:

MOTIVATION FOR...

- FIGURES 4 A, B, C

Salience of motives fo drinking alcoholic

beverages among

alcohol users with

regard to gender, age

and marital status

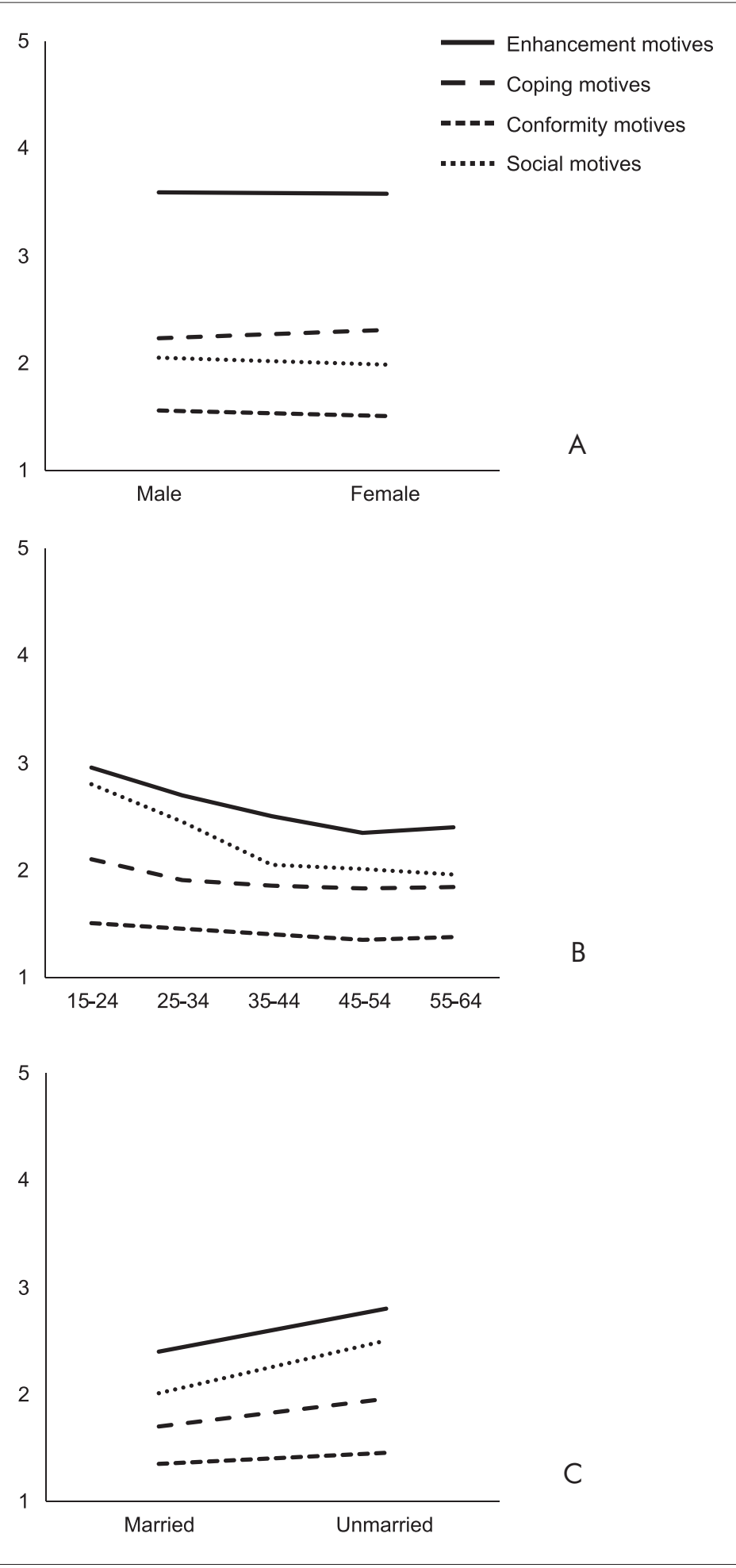


DRUŠ. ISTRAŽ. ZAGREB GOD. 22 (2013), BR. 4 STR. 601-625

GLAVAK TKALIĆ, R. SUČIĆ, I., DEVIĆ, I. MOTIVATION FOR..

$\rightarrow$ FIGURES $5 \mathrm{~A}, \mathrm{~B}, \mathrm{C}$ Salience of motives for smoking tobacco

among tobacco users

with regard to gender,

age and marital status

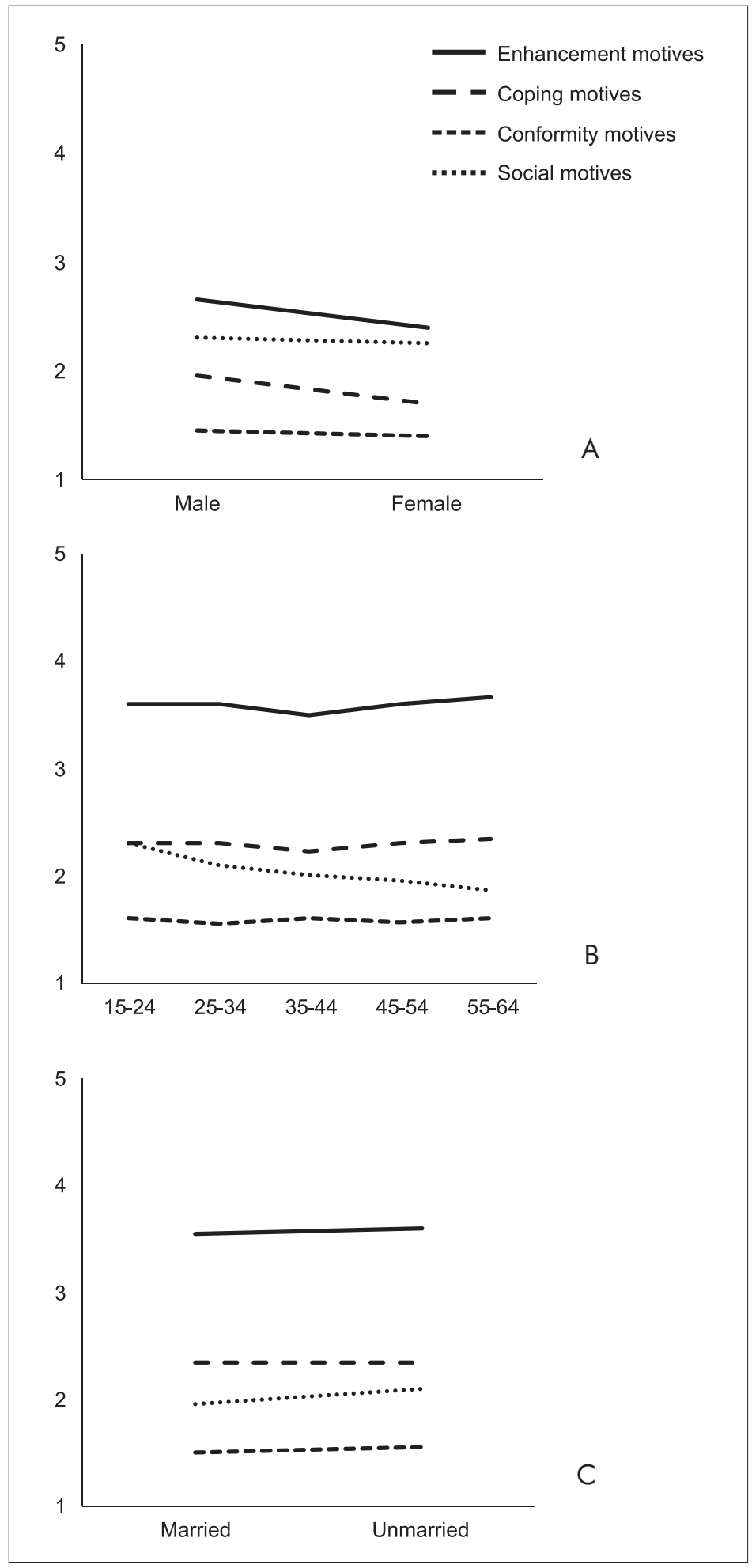


DRUŠ. ISTRAŽ. ZAGREB GOD. 22 (2013), BR. 4, STR. 601-625

GLAVAK TKALIĆ, R., SUČIĆ, I., DEVIĆ, I.: MOTIVATION FOR...

- FIGURES 6 A, B, C Salience of motives for using marijuana among marijuana users with regard to gender, age and marital status

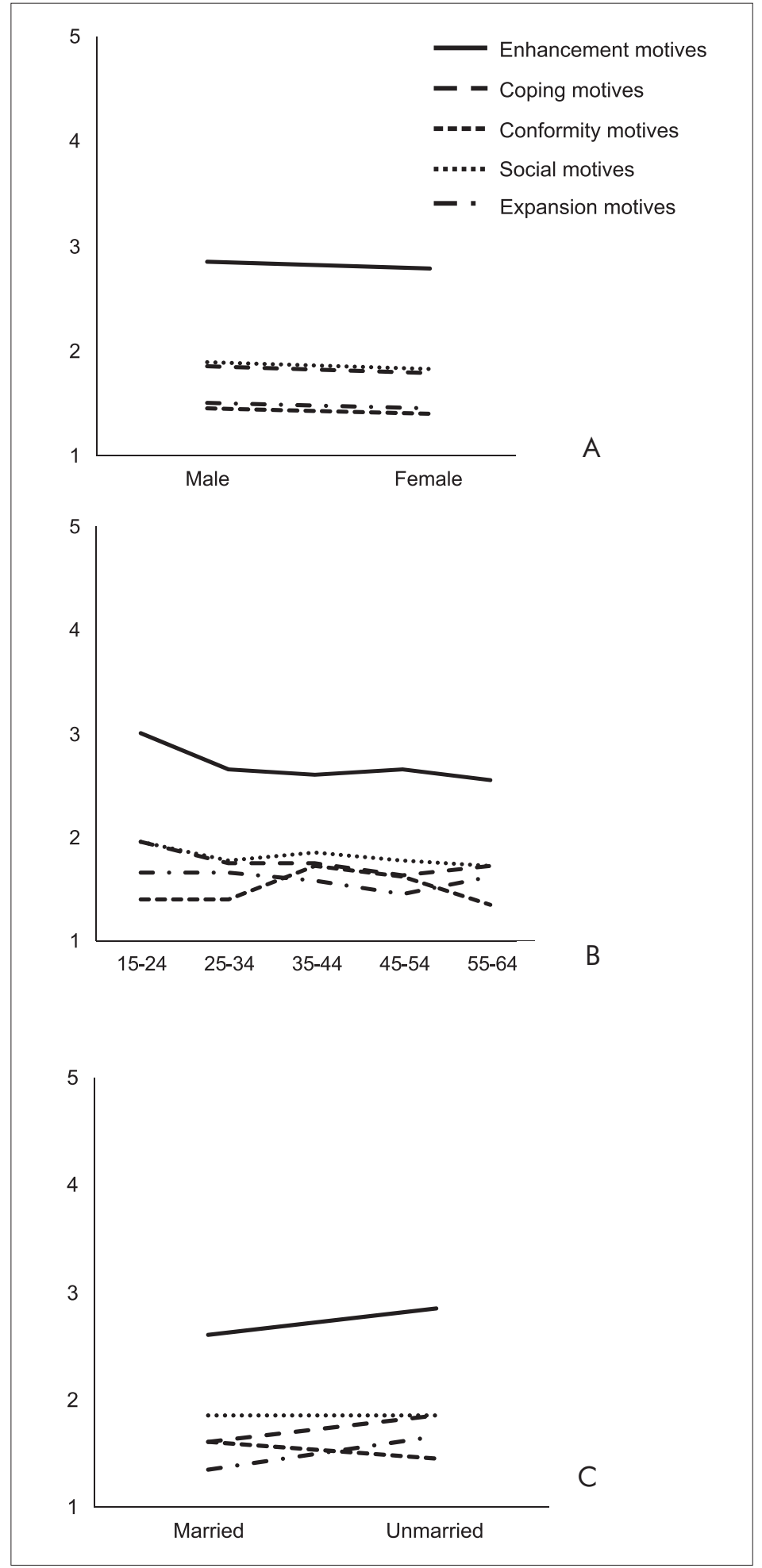


DRUŠ. ISTRAŽ. ZAGREB GOD. 22 (2013), BR. 4 STR. $601-625$

GLAVAK TKALIĆ, R., SUČIĆ, I., DEVIĆ, I. MOTIVATION FOR..

\section{DISCUSSION}

Among tobacco users, there was significant main effect of age on the salience of different motives for smoking tobacco $(F(16,6452)=2.42, p=0.001)$. Differences in motivation for tobacco use were obtained with regard to the age of respondents only for social motives $(F(4,1613)=2.90, p=0.021)$. Post hoc test showed that the oldest group of respondents (aged 55-64) reported weaker social motivation for tobacco use than respondents from the two youngest groups (15-24 and 25-34). Also, the youngest group of respondents (aged 15-24) reported stronger social motivation for tobacco use than respondents from the other two older age groups (35-44 and 45-54) (Figure 5b).

Among marijuana users, there was significant main effect of marital status $(F(5,634)=2.53, p=0.028)$ on the salience of different motives for marijuana use. Marital status of marijuana users had a significant effect only on the salience of expansion motives $(F(1,639)=7.73, p=0.006)$. Unmarried marijuana users were more motivated for marijuana use by expansion motives than the married ones (Figure 6c).

Not surprisingly, respondents primarily reported using alcohol, tobacco and marijuana for the anticipated positive reinforcement - to enhance their positive affect, enjoyment or well-being (see Newcomb et al., 1988 for alcohol use). Positive feelings (e.g. euphoria) induced by substance use represent positive reinforcement and motivation for future use (see Colder \& O'Connor, 2002). In line with previous research (e.g. Abbey, Smith, \& Scott, 1993; Cooper, 1994; Stewart, Zeitlin, \& Samoluk, 1996), additional important motives for alcohol and marijuana use were: achieving positive social incentive followed by the reduction of negative emotions. Not unexpectedly for tobacco use, reduction and management of negative emotions prevailed over the social motives since young people who just started smoking are more prone to smoking for social reasons than those having a well-established smoking habit, like respondents in this research who smoked 5 to 10 years on average (Piper et al., 2004). Social censure or peer rejection proved to be the least prominent motive for the use of all substances.

More severe alcohol, tobacco and marijuana use was primarily internally generated, and mostly motivated by the increase in positive mood and reduction of negative emotions. Overall, frequency of substance use had the smallest effect on the salience of conformity motives.

Previous research reached a similar conclusion on the salience of different motives and its relationship to the severity of substance use. For example, Engels et al. (2005) found 
DRUŠ. ISTRAŽ. ZAGREB GOD. 22 (2013), BR. 4, STR. $601-625$

GLAVAK TKALIĆ, R., SUČIĆ, I., DEVIĆ, I.: MOTIVATION FOR... that enhancement and social motives were more frequently mentioned as reasons for alcohol use compared to coping and conformity motives. Cooper, Frone, Russell, and Mudar (1995) suggested that only people who do not possess more adaptive ways of coping with negative emotions use alcohol as the means to cope with them, and that conformity motives were associated with heavier drinking problems (Bradizza et al., 1999; Carey \& Correia, 1997; Cooper, Russell, Skinner, \& Windle, 1992). Also, social and conformity motives for substance use are expected to be more present among younger respondents (who are not dominant among substance users drawn from the general population), and are likely to weaken with maturity (Cooper, 1994; Martens, Rocha, Martin, \& Serrao, 2008). Also, previous research found enhancement (e.g. enjoyment) and coping (e.g. stress/boredom relief) motives as the highest rated motives for smoking (Fidler \& West, 2009), related to daily cigarette consumption (McEwen, West, \& McRobbie, 2008), increased levels of alcohol use (Cooper, 1994; Kuntsche et al., 2006b), heavier drinking problems (Bradizza et al., 1999; Carey \& Correia, 1997; Cooper et al., 1992), and higher frequency of marijuana use among different populations (Bonn-Miller, Zvolensky, \& Bernstein, 2007; Chabrol et al., 2005; Simons et al., 1998, 2000). Those findings are in line with the proposition that substance use motives could be reduced to the negative and positive reinforcement motive dimensions (Battista et al., 2008). Interestingly, social motives were more commonly associated with infrequent alcohol use and with drinking in social settings (Cooper, 1994; Kuntsche et al., 2006b), contrary to the current study. But in line with the results of current research, social motives were also found to be positively related to more frequent marijuana use (Chabrol et al., 2005; Simons et al., 1998, 2000).

It should be mentioned that conclusions on the relationship between motives for marijuana use and its use are less clear cut. Zvolensky et al. (2007) found that enhancement and social motives were positively, and conformity motives negatively related to marijuana use. However, according to Simons et al. (1998) conformity motives were associated with more problems related to marijuana, and Bonn-Miller et al. (2007) did not found them to be a significant predictor of marijuana use. Also, while in Zvolensky et al. (2007) the research relation between marijuana use and coping motives was not significant, Simons, Gaher, Correia, Hansen, and Christopher (2005) found a significant association. Also, since expansion motive was ranked fourth out of five in the current research, it appears the respondents did not use marijuana so extensively for seeking experiential awareness or perceptual and 
DRUŠ. ISTRAŽ. ZAGREB GOD. 22 (2013), BR. 4 STR. 601-625

GLAVAK TKALIĆ, R., SUČIĆ, I., DEVIĆ, I. MOTIVATION FOR... cognitive enhancement, contrary to Simons et al. (1998), who found that expansion motives account for most of the variance in marijuana use. Consequently, additional research is needed to better understand the convergence and divergence of specific/global motives for substance use.

In the current research, the largest difference in the salience of the motives for marijuana use was found between those who use marijuana least frequently and those who use it moderately but not most frequently, indicating a curvilinear relationship between motives' salience and frequency of marijuana use. However, among alcohol and tobacco users increase in motives' salience corresponds to the increase in frequency of substance use. Similarly, Weinberger, and Bartholomew (1996) found that motivation for drinking in general was associated with increased alcohol consumption, and Engels et al. (2005) conclude that people who drink to deal with personal problems also reported drinking for social reasons.

Relative consistencies of results in the research literature are noticeable, especially for alcohol and tobacco use, as well as overlap between results attained in the current study and previous research. Also, evident are certain regularities between motives' salience among users of different substances, which could be at least partly attributed to the polysubstance use. However, discrepant findings should also be acknowledged, especially those indicating uniqueness of motivation related to specific (il)icit substances. Lyvers et al. (2010) argue that additional variables, related to both motives and behavior are at play (e.g. other individual characteristics) and also, although motives are generally thought to be proximal predictors of behavior, in some situations a person may be motivated to behave in a certain way (e.g. use specific substances) but resist doing it.

The youngest group of respondents in this study showed to be more motivated for tobacco and alcohol use by social motives than respondents of all other age categories, and also more motivated for alcohol use by enhancement motives than the older ones. Results of previous research also showed that social motives were significant determinants of the current smoking status among adolescents (Amin, Amr, \& Zaza, 2011; McEwen et al., 2008), and also most adolescents reported drinking for social and sometimes for enhancement motives (Kuntsche et al., 2005), while older persons were less likely to drink for social reasons (Moran \& Saliba, 2012).

Since social drinkers (Carrigan et al., 1998; Gire, 2002), enhancement drinkers (Kairouz et al., 2002; Lo \& Globetti, 2000; Smith et al., 1993; Stewart et al., 1996), coping drinkers (Cooper, 1994; Gire, 2002), and conformity drinkers (Gire, 2002) 
DRUŠ. ISTRAŽ. ZAGREB GOD. 22 (2013), BR. 4, STR. $601-625$

GLAVAK TKALIĆ, R., SUČIĆ, I., DEVIĆ, I.: MOTIVATION FOR... tend to be male, it was not surprising that men showed to be more motivated by enhancement, coping, conformity and social motives for alcohol use than women in this study, too.

Persons without spouses reported greater importance of social motives and enhancement motives for alcohol use than those with spouses in Kim and Jeon's (2012) research, and in the current study the same also held true for the greater salience of coping and conformity motives for alcohol use among unmarried in comparison to married persons. Another important finding is that unmarried persons were more motivated for marijuana use by expansion motives than married ones. However, further research aimed at explaining why unmarried persons are more motivated for marijuana use by cognitive and perceptual enhancement is needed, as well as research which will explore the role of socio-demographic variables in the motivation for different types of substance use more thoroughly.

This study's findings support the importance of understanding different motives for substance use, since they are not all equally important and common for all, and must be observed separately for people of different age, gender, and marital status. A lack of discrimination between the motives for use of different substances may be evidence of their common reinforcement properties, but may also indicate that endorsement of the motive is more related to personality variables than specific anticipated substance effects (Simons et al., 1998).

\section{Strengths and limitations}

Since most of the previous studies on substance use motives are conducted among relatively homogenous samples of young people, the primary strength of this study is the potential significant generalizability of its results due to a large nationally representative sample of heterogeneous respondents. Also, this is one of the rare studies that examines the motives for both licit (tobacco, alcohol) and illicit (marijuana) substances, and which also explores differences in motives for substance use with regard to several socio-demographic variables.

However, the present study also has certain limitations. The study is cross-sectional and it uses self-report measures of participants' substance use, as well as of motives for its use. Scales for assessing tobacco and marijuana use motives rely on an adapted questionnaire of alcohol use motives, and it is possible that these scales may not capture all the motives $\mathrm{u}$ nique to tobacco and marijuana use although a specific motive (expansion) for marijuana use, was added. A shortened 
DRUŠ. ISTRAŽ. ZAGREB GOD. 22 (2013), BR. 4 STR. $601-625$

GLAVAK TKALIĆ, R., SUČIĆ, I., DEVIĆ, I. MOTIVATION FOR.. psychometrics, especially since each motive was represented by only two items, and since the enhancement subscale for alcohol use tends to have a relatively low internal consistency coefficient. Furthermore, motive subscales tend to be significantly correlated with one another, which is consistent with the results of previous research (Simons et al., 1998; Cooper et al., 1992; Stewart et al., 1996), but it is possible that there is a higher-order factor of motivation for substance use. Since severity measures of substance use were not included in this study, the frequency of use was the only estimate of its severity.

In further studies, performance of shortened motive scales in different populations of substance users is needed, as well as further development of a motives' measure for specific but also polysubstance use. Future research will surely benefit from the multiple indicators of (il)licit substance use severity. Also, longitudinal data would give more in-depth insight into the stability and change of motives for (il)licit substance use, separating the influence of confounding factors.

For understanding substance use and its motivation, it is important to consider other factors that affect substance use, like those biological, genetic, psychological, environmental, but also to take into consideration the nature of the sample and the possibility that some confounding research factors might have influenced the findings (e.g. disproportional refusal by a certain group of people, non-existing information on the presence of other psychopathology). There is a great quantity of research in which the substantial proportion of the variability in substance use is predicted by factors not captured by this type of research.

Despite the mentioned limitations, this research provides a fruitful context for future studies to investigate the influence of specific motives on the etiology of (il)licit substance use. Understanding the motives for substance use with regard to personal characteristics of its users is very useful for planning motive-specific prevention and intervention strategies.

\section{NOTES}

1 Survey methodology is described in detail in: Glavak Tkalić, R., Miletić, G. M., Maričić, J., \& Wertag, A. (2012). Substance Abuse among the General Population in the Republic of Croatia: Research Report. Zagreb: Institute of Social Sciences Ivo Pilar and Government of the Republic of Croatia - Office for Combating Drug Abuse. Retrieved from http://www.pilar.hr/images/stories/dokumenti/elaborati/substance_ abuse_among.pdf

2 The major causes of non-participation was refusal ( $N=4721$, including the situations in which the interviewer even after three attempts was not able to make contact with the selected household member), the frame error $(\mathrm{N}=1110$, household was without a mem- 
DRUŠ. ISTRAŽ. ZAGREB GOD. 22 (2013), BR. 4, STR. $601-625$

GLAVAK TKALIĆ, R., SUČIĆ, I., DEVIĆ, I.: MOTIVATION FOR...

\section{REFERENCES}

ber aged between 15 and 64, or property was vacant, derelict, demolished, not found, or used only for business), and incorrectly filled questionnaires by the interviewer $(\mathrm{N}=75)$. The main reasons for the selected respondents' non-participation were household non-co-operation $(23.2 \%)$, nobody at home $(17.0 \%)$, subject non-co-operation $(4.4 \%)$, selected subject not at home $(2.3 \%)$.

3 This way adequate sample sizes were assured to conduct analyses to explore differences in the salience of different motives for marijuana use with regard to age, gender and marital status.

4 Since the respondents' age ranged from 15 to 64 , the age groups were determined based on a principle of decades, and approximately the same share of respondents were in each age category.

${ }^{5}$ It should be noted that the largest proportion of the respondents in this survey concurrently used alcohol and tobacco in the past month $(48.7 \%)$, and around a quarter $(25.7 \%)$ used alcohol and tobacco in the month prior to the survey and also used marijuana at least once during their life-time. Subscales for measuring motives were substance specific (e.g. "I drink so I won't feel left out") and thus not applicable for addressing the motivation for polysubstance use, but additional t-tests performed in order to determine whether sole-substance users use specific substance for one motive, while polysubstance users use the same substance for different motives showed that sole tobacco users in comparison to polysubstance users had significantly less pronounced conformity $(\mathrm{t}(318,1280)=2.170, p=0.030)$ and social $(\mathrm{t}(319,1280)=3.741, p=0.000)$ motives. Since the proportion of the sole marijuana users was too small for any meaningful comparison $(\mathrm{N}=2)$, and no significant differences were found in the salience of any motive for alcohol use between groups of sole alcohol users and polysubstance users, further research that will address this issue in-depth is needed.

6 Those results were confirmed by regression analysis for each substance use. Motives for substance use were entered as predictors and frequency of substance use as criteria. Simultaneously entered motives explained in total $5.3 \%$ of frequency of tobacco use, $6 \%$ of frequency of alcohol use, and 17,3\% of frequency of marijuana use. Enhancement motive showed to be a significant predictor of the frequency of tobacco $(\beta=0.180, p=0.000)$, alcohol $(\beta=0.195, p=0.000)$ and marijuana $(\beta=0.302, p=0.003)$ use. Coping $(\beta=0.121, p=0.000$, and $\beta=0.152, p=0.000$ respectively) and social motives $(\beta=0.062$, $p=0.049$, and $\beta=0.117, p=0.000$ respectively) were significant predictors of the frequency of tobacco and alcohol use.

7 Since all interaction effects showed to be insignificant, data were not presented in Tables 4 and 5 .

Abbey, A., Smith, M. J., \& Scott, R. O. (1993). The relationship between reasons for drinking alcohol and alcohol consumption: An interactional approach. Addictive Behaviors, 18(6), 659-670. doi:10.1016/ 0306-4603(93)90019-6

Amin, T. T., Amr, M. A., \& Zaza, B. O. (2011). Psychosocial predictors of smoking among secondary school students in Al-Hassa, Saudi Arabia. Journal of Behavioral Medicine, 34(5), 339-350. doi:10.1007/s10865- 011-319-7 
DRUŠ. ISTRAŽ. ZAGREB GOD. 22 (2013), BR. 4 STR. $601-625$

GLAVAK TKALIĆ, R., SUČIĆ, I., DEVIĆ, I.: MOTIVATION FOR.
Battista, S. R., Stewart, S. H., Fulton, H. G., Steeves, D., Darredeau, C., \& Gavric, D. (2008). A further investigation of the relations of anxiety sensitivity to smoking motives. Addictive Behaviors, 33(11), 1402-1408. doi:10.1016/j.addbeh.2008.06.016

Bonn-Miller, M. O., Zvolensky, M. J., \& Bernstein, A. (2007). Marijuana use motives: Concurrent relations to frequency of past 30-day use and anxiety sensitivity among young adult marijuana smokers. Addictive Behaviors, 32(1), 49-62. doi:10.1016/j.addbeh.2006.03.018

Bradizza, C. M., Reifman, A., \& Barnes, G. (1999). Social and coping reasons for drinking: Predicting alcohol misuse in adolescents. Journal of Studies on Alcohol, 60(4), 491-499.

Carey, K. B., \& Correia, D. J. (1997). Drinking motives predict alcohol-related problems in college students. Journal of Studies on Alcohol, 58(1), 100-105.

Carrigan, G., Samoluk, S. B., \& Stewart, S. H. (1998). Examination of the short form of the inventory of drinking situations (IDS-42) in a young adult university student sample. Behaviour Research and Therapy, 36(7-8), 789-807. doi:10.1016/S0005-7967(98)00024-2

Chabrol, H., Ducongé, E., Casas, C., Roura, C., \& Carey, K. B. (2005). Relations between cannabis use and dependence, motives, for cannabis use and anxious, depressive and borderline symptomatology. Addictive Behaviors, 30(4), 829-840. doi:10.1016/j.addbeh.2004.08.027

Colder, C. R., \& O'Connor, R. (2002). Attention bias and disinhibited behaviour as predictors of alcohol use and enhancement reasons for drinking. Psychology of Addictive Behaviours, 16(4), 325-332. doi:10.1037/ 0893-164X.16.4.325

Comeau, N., Stewart, S. H., \& Loba, P. (2006). The relations of trait anxiety, anxiety sensitivity, and sensation seeking to adolescents' motivations for alcohol, cigarette, and marijuana use. Addictive Behaviors, 26(6), 803-825. doi:10.1016/S0306-4603(01)00238-6

Cooper, M. L. (1994). Motivations for alcohol use among adolescents: Development and validation of a four-factor model. Psychological Assessment, 6(2), 117-128. doi:10.1037/1040-3590.6.2.117

Cooper, M. L., Frone, M. R., Russell, M., \& Mudar, P. (1995). Drinking to regulate positive and negative emotions: A motivational model of alcohol use. Journal of Personality and Social Psychology, 69(3), 990-1005. doi:10.1037//0022-3514.69.5.990

Cooper, M. L., Russell, M., Skinner, J. B., \& Windle, M. (1992). Development and validation of a three-dimensional measure of drinking motives. Psychological Assessment, 4(2), 123-132. doi:10.1037/1040-3590. 4.2.123

Cox, W. M., \& Klinger, E. A. (1988). A motivational model of alcohol use. Journal of Abnormal Psychology, 97(2), 168-180. doi:10.1037//0021843X.97.2.168

Crutzen, R. \& Kuntsche, E. (2013). Validation of the four-dimensional structure of drinking motives among adults. European Addiction Research, 19(4), 222-226. doi:10.1159/000345457

Dejanović, D. (2011). Povezanost anksiozne osjetljivosti, anksioznosti, depresivnosti i motivacije za konzumaciju sredstava ovisnosti. [The rela- 
DRUŠ. ISTRAŽ. ZAGREB GOD. 22 (2013), BR. 4, STR. $601-625$

GLAVAK TKALIĆ, R., SUČIĆ, I., DEVIĆ, I.: MOTIVATION FOR... tionship between anxiety sensitivity, anxiety, depression and motivation for substance abuse]. (Unpublished Master Thesis). University of Zagreb, Centre for Croatian Studies, Zagreb.

Engels, R. C. M. E., Wiers, R., Lemmers, L., \& Overbeek, G. (2005). Drinking motives, alcohol expectancies, self-efficacy, and drinking patterns. Journal of Drug Education, 35(2), 147-166. doi:10.2190/6Q6B3LMA-VMVA-L312

European Monitoring Centre for Drugs and Drug Addiction (EMCDDA). (2002). Handbook for surveys on drug use among the general population. EMCDDA Project CT.99.EP.08 B. Lisabon: EMCDDA.

Fidler, J. A., \& West, R. (2009). Self-perceived smoking motives and their correlates in a general population sample. Nicotine $\mathcal{E}$ Tobacco Research, 11(10), 1182-1188. doi:10.1093/ntr/ntp120

Gire, J. T. (2002). A cross-national study of motives for drinking alcohol. Substance Use and Misuse, 37(2), 215-223. doi:10.1081/JA-120001978

Glavak Tkalić, R., Miletić, G. M., Maričić, J., \& Wertag, A. (2012). Substance abuse among the general population in the Republic of Croatia: Research report. Zagreb: Institute of Social Sciences Ivo Pilar and Government of the Republic of Croatia - Office for Combating Drug Abuse. Available on http://www.pilar.hr/images/stories/dokumenti/ elaborati/substance_abuse_among.pdf

Hawkins, L. W. (2006). The impact of personality and affect on college students' motives for marijuana use. (Unpublished doctoral dissertation). School of Graduate Studies Indiana State University Terre Haute, Indiana.

Ikard, F. F., Green, D. E., \& Horn, D. (1969). A scale to differentiate between types of smoking as related to the management of affect. International Journal of the Addictions, 4(4), 649-659.

Kairouz, S., Gliksman, L., Demers, A., \& Adlaf, E. M. (2002). For all these reasons, I do...drink: A multilevel analysis of contextual reasons for drinking among Canadian undergraduates. Journal of Studies on Alcohol, 63(5), 600-608.

Kim, O., \& Jeon, H. O. (2012). Relations of drinking motives and alcohol consumption in Korean male office workers. Psychological Reports, 111(3), 963-970. doi:10.2466/18.06.13.PR0.111.6.963-970

Kuntsche, E., Knibbe, R., Gmel, G., \& Engels, R. (2006a). Replication and validation of the Drinking Motive Questionnaire Revised (DMQ-R, Cooper, 1994) among adolescents in Switzerland. European Addiction Research, 12(3), 161-168. doi:10.1159/000092118

Kuntsche, E., Knibbe, R., Gmel, G., \& Engels, R. (2006b). Who drinks and why? A review of socio-demographic, personality, and contextual issues behind the drinking motives in young people. Addictive Behaviors, 31(10), 1844-1857. doi:10.1016/j.addbeh.2005.12.028

Kuntsche, E., Knibbe, R., Gmel, G., \& Engels, R. (2005). Why do young people drink? A review of drinking motives. Clinical Psychology Review, 25(7), 841-861. doi:10.1016/j.cpr.2005.06.002

Lee, C. M., Neighbors, C., Hendershot, C. S., \& Grossbard, J. R. (2009). Development and preliminary validation of a comprehensive marijuana motives questionnaire. Journal of Studies on Alcohol and Drugs, 70(2): 279-287. 
DRUŠ. ISTRAŽ. ZAGREB GOD. 22 (2013), BR. 4 STR. $601-625$

GLAVAK TKALIĆ, R. SUČIĆ, I., DEVIĆ, I.: MOTIVATION FOR.
Lee, C. M., Neighbors, C., \& Woods, B. (2007). Marijuana motives: Young adults' reasons for using marijuana. Addictive Behaviors, 32(7), 1384-1394. doi:10.1016/j.addbeh.2006.09.010

Livson, N., \& Leino, E. V. (1998). Cigarette smoking motives: Factorial structure and gender differences in a longitudinal study. Substance Use E Misuse, 23(6), 535-544. doi:10.3109/10826088809039218

Lo, C. C., \& Globetti, G. (2000). Gender differences in drinking patterns among Hong Kong Chinese youth: A pilot study. Substance Use $\mathcal{E}$ Misuse, 35(9), 1297-1306. doi:10.3109/10826080009147483

Lyvers, M., Hasking, P., Hani, R., Rhodes, M., \& Trew, E. (2010). Drinking motives, drinking restraint and drinking behaviour among young adults. Addictive Behaviors, 35(2), 116-122. doi:10.1016/j.addbeh. 2009.09.011

MacLean, M. G., \& Lecci, L. (2000). A comparison of models of drinking motives in a university sample. Psychology of Addictive Behaviors, 14(1), 83-87. doi:10.1037/0893-164X.14.1.83

Martens, M. P., Rocha, T. L., Martin, J. L., \& Serrao, H. F. (2008). Drinking motives and college students: Further examination of a four-factor model. Journal of Counseling Psychology, 55(2), 289-295. doi:10. 1037/0022-0167.55.2.289

McEwen, A., West, R., \& McRobbie, H. (2008). Motives for smoking and their correlates in clients attending stop smoking treatment services. Nicotine E Tobacco Research, 10(5), 843-850. doi:10.1080/146222 00802027248

Moran, C. C., \& Saliba, A. J. (2012). Reasons for drinking wine and other beverages - comparison across motives in older adults. International Journal of Wine Research, 4(1), 25-32. doi:10.2147/IJWR.S33323

Newcomb, M. D., Chou, C., Bentler, P. M., \& Huba, G. J. (1988). Cognitive motivations for drug use among adolescents: Longitudinal tests of gender differences and predictors of change in drug use. Journal of Counseling Psychology, 35(4), 426-438. doi:10.1037/00220167.35.4.426

Piper, M. E., Piasecki, T. M., Federman, E. B., Bolt, D. M., Smith, S. S., Fiore, M. C., \& Baker, T. B. (2004). A multiple motives approach to tobacco dependence: The Wisconsin Inventory of Smoking Dependence Motives (WISDM). Journal of Consulting and Clinical Psychology, 72(2), 139-154. doi:10.1037/0022-006X.72.2.139

Pomerleau, O. F., Fagerström, K., Marks, J. L., Tate, J. C., \& Pomerleau, C. S. (2003). Development and validation of a self-rating scale for positive- and negative-reinforcement smoking: The Michigan Nicotine Reinforcement Questionnaire. Nicotine and Tobacco Research, 5(5), 711-718. doi:10.1080/1462220031000158627

Pomerleau, C. S., Pomerleau, O. F., Flessland, K. A., \& Basson, S. M. (1992). Relationship of tridimensional personality questionnaire scores and smoking variables in female and male smokers. Journal of Substance Abuse, 4(2), 143-154. doi:10.1016/0899-3289(92)90014-O

Rossi, J. S., Prochaska, J. O., \& DiClemente, C. C. (1988). Processes of change in heavy and light smokers. Journal of Substance Abuse, 1(1), 1-9. doi:10.1016/S0899-3289(88)80003-8 
DRUŠ. ISTRAŽ. ZAGREB GOD. 22 (2013), BR. 4, STR. $601-625$

GLAVAK TKALIĆ, R., SUČIĆ, I., DEVIĆ, I.: MOTIVATION FOR...
Simons, J., Correia, C. J., \& Carey, K. B. (2000). A comparison of motives for marijuana and alcohol use among experienced users. Addictive Behaviors, 25(1), 153-160. doi:10.1016/S0306-4603(98)00104-X

Simons, J., Correia, C. J., Carey, K. B., \& Borsari, B. E. (1998). Validating a five-factor marijuana motives measure: Relations with use, problems, and alcohol motives. Journal of Counseling Psychology, 45(3), 265-273. doi:10.1037/0022-0167.45.3.265

Simons, J., Gaher, R., Correia, C. J., Hansen, C. L., \& Christopher, M. S. (2005). An affective-motivational model of marijuana and alcohol problems among college students. Psychology of Addictive Behaviors, 19(3), 326-334. doi:10.1037/0893-164X.19.3.326

Smith, M. J., Abbey, A., \& Scott, R. O. (1993). Reasons for drinking alcohol: Their relationship to psychosocial variables and alcohol consumption. International Journal of the Addictions, 28(9), 881-908. doi:10. 3109/10826089309039662

Stewart, S. H., Zeitlin, S. B., \& Samoluk, S. B. (1996). Examination of a three-dimensional Drinking Motives Questionnaire in a young adult university student sample. Behaviour Research and Therapy, 34(1), 61-71. doi:10.1016/0005-7967(95)00036-W

Tate, J. C., Pomerleau, C. S., \& Pomerleau, O. F. (1994). Pharmacological and non-pharmacological smoking motives: A replication and extension. Addiction, 89(3), 321-330. doi:10.1111/j.1360-0443.1994.tb00899.x

Weinberger, D., \& Bartholomew, K. (1996). Social-emotional adjustment and patterns of alcohol use among young adults. Journal of Personality, 64(2), 495-527. doi:10.1111/j.1467-6494.1996.tb00519.x

Zvolensky, M. J., Vujanovic, A. A., Bernstein, A., Bonn-Miller, M. O., Marshall, E. C., \& Leyro, T. M. (2007). Marijuana use motives: A confirmatory test and evaluation among young adult marijuana users. Addictive Behaviors, 32(12), 3122-3130. doi:10.1016/j.addbeh.2007.06.010

\section{Motivacija za uporabu sredstava ovisnosti: zašto ljudi konzumiraju alkohol, duhan i marihuanu?}

Renata GLAVAK TKALIĆ, Ines SUČIĆ, Ivan DEVIĆ Institut društvenih znanosti Ivo Pilar, Zagreb

Cilj istraživanja bio je ispitati istaknutost različitih motiva za uporabu sredstava ovisnosti među konzumentima alkohola, duhana i marihuane te ispitati razlike $u$ istaknutosti različitih motiva s obzirom na učestalost konzumiranja navedenih sredstava ovisnosti i socio-demografskih karakteristika sudionika. Podaci su prikuplieni na poduzorcima konzumenata alkohola, duhana i marihuane iz reprezentativnog uzorka građana Hrvatske $(N=4756)$. Sudionici su procjenjivali četiri motiva za uporabu alkohola i duhana (motiv podizanja raspoloženja, socijalni motiv, motiv konformiranja i motiv suočavanja), a za uporabu marihuane i peti motiv 
DRUŠ. ISTRAŽ. ZAGREB GOD. 22 (2013), BR. 4 STR. 601-625

GLAVAK TKALIĆ, R., SUČIĆ, I., DEVIĆ, I. MOTIVATION FOR.. (motiv proširenja svijesti). Motivi podizanja raspoloženja procijenjeni su kao najzastuplieniji, a motivi konformiranja kao najmanje zastuplieni među svim skupinama konzumenata sredstava ovisnosti. Općenito, povećana istaknutost motiva povezana je s učestalosti uporabe svih sredstava ovisnosti. Dob je imala značajan učinak na istaknutost socijalnih motiva za pušenje duhana, spol i bračni status na istaknutost svih motiva za konzumaciju alkohola, dok je dob imala značajan učinak samo na istaknutost motiva podizanja raspoloženja i socijalne motive za konzumaciju alkohola. Među konzumentima marihuane samo je bračni status imao značajan učinak na istaknutost motiva proširenja svijesti za uporabu marihuane. Rezultati su analizirani u okviru motivacijskih modela za uporabu sredstava ovisnosti.

Ključne riječi: alkohol, pušenje, marihuana, motivi za uporabu sredstava ovisnosti, socio-demografske varijable 